\title{
A LOCOMATECH H-2020 PROJEKT ALAKÍTÁSTECHNOLÓGIAI VONATKOZÁSAI ÉS EREDMÉNYEI
}

\author{
Gál Gaszton \\ címzetes egyetemi docens, Miskolci Egyetem, Anyagszerkezettani és Anyagtechnológiai Intézet \\ 3515 Miskolc, Miskolc-Egyetemváros, e-mail: metgalga@uni-miskolc.hu \\ Gál Viktor \\ PhD hallgató, Miskolci Egyetem, Anyagszerkezettani és Anyagtechnológiai Intézet \\ 3515 Miskolc, Miskolc-Egyetemváros, e-mail: gal.viktor@uni-miskolc.hu

\section{Kovács Péter Zoltán} \\ egyetemi docens, Miskolci Egyetem, Anyagszerkezettani és Anyagtechnológiai Intézet \\ 3515 Miskolc, Miskolc-Egyetemváros, e-mail: metkpz@uni-miskolc.hu

\section{Kuzsella László} \\ egyetemi docens, Miskolci Egyetem, Anyagszerkezettani és Anyagtechnológiai Intézet \\ 3515 Miskolc, Miskolc-Egyetemváros, e-mail: femkuzsy@uni-miskolc.hu

\section{Lukács Zsolt} \\ egyetemi docens, Miskolci Egyetem, Anyagszerkezettani és Anyagtechnológiai Intézet \\ 3515 Miskolc, Miskolc-Egyetemváros, e-mail: zzsolt.lukacs@uni-miskolc.hu

\section{Tisza Miklós} \\ professzor emeritus, Miskolci Egyetem, Anyagszerkezettani és Anyagtechnológiai Intézet \\ 3515 Miskolc, Miskolc-Egyetemváros, e-mail: tisza.miklos@uni-miskolc.hu
}

\begin{abstract}
Absztrakt
A cikk a LoCoMaTech H-2020 projekt keretében végzett alakitástechnológiai kutatásokról és az elért eredményekröl ad számot. A projekt a Horizon 2020 Európai Uniós program keretében nyert el pályázati támogatást a 2016.09.01-2019.08.31. közötti, 36 hónapos kutatási idöszakra. A projekt szakmai feladatait 9 ország 19 intézményéböl álló konzorcium valósitotta meg a Londoni Imperial College vezetésével. A projekt fö célja elsösorban nagyszilárdságú (pl. AA6082 és AA7075 anyagminöségü) aluminium ötvözetek alkalmazásával, jelentös tömegcsökkentéssel, költséghatékony gyártási eljárások kidolgozása, a környezeti káros hatások minél nagyobb mértékü csökkentésével. A projektben a Miskolci Egyetem Anyagszerkezettani és Anyagtechnológiai Intézetének Mechanikai Technológiai Intézeti Tanszéke volt a magyar partner, amelynek fö feladatát az alakitástechnológiai kérdések vizsgálata, alakithatósági kísérletek végzése, valamint ezek numerikus modellezése képezte.
\end{abstract}

Kulcsszavak: tömegcsökkentés, jármüipar, nagyszilárdságú Al-ötvözetek alkalmazása, alakithatóság

\section{Abstract}

In this paper, the formability investigations and their results achieved within the LoCoMaTech H-2020 project are summarised. This Joint European project was realised by the consortium of 19 institutions and companies from nine European countries. The project was led by the Imperial College London (ICL). The primary aim of the project was to develop a cost-effective process for producing 
automotive parts from low-density aluminium alloys (e.g. AA6082 és AA7075 high strength grades), to assure significant mass reduction and thereby reducing the harmful emissions and contributing to the environment protection. Performing theoretical and experimental formability investigations and numerical modelling was the main task of the Institute of Materials Science \& Technology of the University of Miskolc as the Hungarian project partner.

Keywords: mass reduction, automotive industry, high strength aluminium alloys, formability investigations

\section{Bevezetés}

A LoCoMaTech H-2020 projekt az Imperial College London (ICL) vezetésével 2016 szeptemberében indult, 36 hónap futamidejü az EU által finanszírozott, Horizon-2020 kutatási együttműködés. A projekt fő célkitüzése nagyszilárdságú Al-ötvözetek felhasználásával készült járműalkatrészek gazdaságos elóállítási technológiájának, az ún. Hot Forming \& Quenching (HFQ $\left.{ }^{\mathrm{TM}}\right)$ szabadalmaztatott eljárás optimális technológiai megoldásainak kidolgozása, az eljárás paramétereinek meghatározása és a tömeggyártásba történő bevezethetőségének vizsgálata.

1. táblázat. A munkacsoportok (Work Packages) megnevezése és a koordináló intézmény

\begin{tabular}{|c|c|c|}
\hline $\begin{array}{c}\text { WP } \\
\text { Number }\end{array}$ & WP megnevezése & WP koordinátor intézmény \\
\hline WP1 & $\begin{array}{l}\text { Integrated Cost-driven Life Cycle Approach and } \\
\text { Implementation - Integrált, költség-orientált életciklus- } \\
\text { megközelítés és megvalósitás }\end{array}$ & $\begin{array}{l}\text { Centro Ricerche Fiat SCPA - } \\
\text { CRF }\end{array}$ \\
\hline WP2 & $\begin{array}{l}\text { Materials, Testing and Characterisation for low cost } \\
\text { HFQ }{ }^{\circledR} \text { - Anyagok, vizsgálatok és anyagjellemzök a kis } \\
\text { költségú } H F Q \circledR \text { eljárás céljára }\end{array}$ & Constellium CRV SAS - CTE \\
\hline WP3 & $\begin{array}{l}\text { Innovative Low-Cost Manufacturing Technologies - } \\
\text { Innovatív, kis költségü gyártási eljárások kidolgozása }\end{array}$ & $\begin{array}{l}\text { Imperial College of Science } \\
\text { Technology - ICL }\end{array}$ \\
\hline WP4 & $\begin{array}{l}\text { Sustainable Manufacturing System and Tools - } \\
\text { Fenntartható gyártási rendszerek és eszközök fejlesztése }\end{array}$ & $\begin{array}{l}\text { Automation, Press and Tooling } \\
\text { A.P.\& T. - APT }\end{array}$ \\
\hline WP5 & $\begin{array}{l}\text { Design for Materials Replacement and Virtual Engineering } \\
\text { - Tervezés és helyettesítő anyagok kiválasztása Virtuális } \\
\text { mérnöki tevékenységgel }\end{array}$ & $\begin{array}{l}\text { Impression Technologies } \\
\text { Limited - ITL }\end{array}$ \\
\hline WP6 & $\begin{array}{l}\text { Technology and Product Demonstration, Validation and } \\
\text { Industrial Assessments - Technológiai és termék } \\
\text { demonstráció, validálás és ipari felmérések }\end{array}$ & $\begin{array}{l}\text { Voestalpine Polynorm Gmbh \& } \\
\text { Co. KG - VAP }\end{array}$ \\
\hline WP7 & $\begin{array}{l}\text { Dissemination, Exploitation, Training and Educational } \\
\text { Courses - Az eredmények disszeminációja, hasznosítása, } \\
\text { képzési és oktatási kurzusok }\end{array}$ & Diad Group Srl - DIG \\
\hline WP8 & $\begin{array}{l}\text { Project Administrative and Financial Management - A } \\
\text { projekt adminisztratív és pénzügyi menedzselése }\end{array}$ & $\begin{array}{l}\text { Imperial College Of Science } \\
\text { Technology - ICL }\end{array}$ \\
\hline
\end{tabular}


A projektben 9 Európai Uniós országból összesen 19 partner intézmény vett részt. A kutatás feladatait a konzorcium 8 munkacsoportra (Work Package) bontva, és az egyes munkacsoportokon belül létrehozott feladatokpontok (Task Point) szerint végezte. A munkacsoportok és azokon belül a feladatpontok a teljes projekt logikus megvalósítási rendszerét alkották.

Mind a nyolc munkacsoport (WP1-WP8) feladatait egy-egy kijelölt konzorciumi intézmény koordinálta és a feladatpontok vezetését is egy-egy konzorciumi intézmény látta el. Ebben a H-2020 projektben a Kelet-Közép Európai országokból egyedüli partnerként az ME-ATI Mechanikai Technológiai Intézeti Tanszéke vett részt.

A Miskolci Egyetem Anyagszerkezettani és Anyagtechnológiai Intézete (ME-ATI) az 2. táblázatban felsorolt munkacsoportok közül a WP2, WP3, WP5, WP6, WP7 és WP8 munkacsoportokban végzett kutatómunkát; a WP2-n belül az Alumínium ötvözetek mechanikai anyagvizsgálata és az Alakíthatósági vizsgálatok (TaskPoint 2.4. Materials Testing and Formability Investigations) feladatpontban, valamint aWP3 munkacsoportban az azonos és különbözö anyagminőségü anyagok különféle kötéstechnológiáinak kidolgozásában és vizsgálataiban elnevezésü feladatpont (TaskPoint 3.5. és 3.6.) irányítását is ellátta. A többi felsorolt munkacsoportban, közremüködő intézményként végeztünk feladatokat. Értelemszerüen, a feladatok jellegéből következően a WP6, WP7 és WP8 munkacsoportban valamennyi partner intézmény részt vett.

A 36 hónap kutatómunkája igen szerteágazó feladatokat jelentett: ezek közül ebben a cikkben az alumínium ötvözetek mechanikai tulajdonság vizsgálatából és az alakíthatósági elemzésekből közlünk szemelvényeket. Mind az anyagparaméterek meghatározása, mind pedig az alakíthatósági elemzések a többi munkacsoport feladataihoz szolgáltatnak alapvető jelentőségủ adatokat és információkat.

\section{A Hot Forming \& Quenching $\left(H F Q{ }^{\circledR}\right)$ eljárás ismertetése}

Amint a Bevezetésben is említettük a projekt fö célkitüzése a nagyszilárdságú Al-ötvözetek felhasználásával készült járműalkatrészek gazdaságos előállítási technológiájának, az ún. Hot Forming \& Quenching $\left(\mathrm{HFQ}^{\mathrm{TM}}\right)$ szabadalmaztatott eljárásnak a részletes technológiai kidolgozása, az eljárás optimális technológiai megoldásainak továbbfejlesztése, valamint az eljárás optimális paramétereinek meghatározása és a tömeggyártásba történő bevezethetőségének vizsgálata volt. Ennek részletezése elött indokolt, hogy röviden összefoglaljuk az eljárás lényegét.

A tömegcsökkentés követelményének - amely az autóiparral szemben támasztott követelmények szinte mindegyike szempontjából kiemelt jelentőségü - egyik lehetséges megvalósítási útja a könnyüfémek csoportjába tartozó, nagyszilárdságú alumínium ötvözetek alkalmazása. Ugyanakkor az is közismert, hogy a szilárdság növelésével az alakíthatóság rohamosan csökken, miközben az autóipari alkatrészek többségét - különösen az ún. Body-in-White, azaz a karosszéria elemeket vékonylemezből, képlékenyalakítással gyártják, tehát az alakíthatóság kiemelt fontosságú az autóiparban. A megoldás ezért olyan technológiai folyamat alkalmazása, amelynél az alakítás során az alkalmazott alumínium ötvözet még kis szilárdsággal és jó alakíthatósággal rendelkezik, és amelynél az alkatrész a megkívánt szilárdságát az alakítás után, utólagos hőkezeléssel, kikeményítéssel éri el. Az alakítható, nemesíthető alumínium ötvözetek ennek a technológiai folyamatnak kiválóan megfelelnek, közülük is elsősorban azok az ötvözetek, amelyek a kikeményítő hőkezelés során a legnagyobb szilárdságot biztosítják. Ennek a követelménynek leginkább az ún. 7xxx ötvözetsor felel meg, közülük is leginkább az AA7075 jelü, Al-Zn-Mg-Cu ötvözet.

Az AA7075 alumínium ötvözet a repülőgépipar és egyre inkább az alumínium karosszériát fejlesztő autóipar közkedvelt anyagává vált. Ez az alumínium ötvözet a nemesíthető alumínium 
ötvözetek jellegzetes képviselője, amely a magas hőmérsékletủ $\left(480-525^{\circ} \mathrm{C}\right)$ oldó izzítást követően jól alakítható, lágy homogén egyfázisú, $\alpha$ szilárd oldatot tartalmaz, a kikeményítést követően pedig egyes acélok szilárdságát is elérő $\left(\mathrm{R}_{\mathrm{m}}>550 \mathrm{MPa}\right)$ nagyszilárdságú ötvözetet kapunk.

Ezek a paraméterek teszik ezt az alumínium ötvözetet kiválóan alkalmassá a Hot Forming and Quenching $\left(\mathrm{HFQ}^{\mathrm{TM}}\right)$ eljárásra, amelynek lényege az alábbiakban foglalható össze: az alumínium ötvözetet nagyhőmérsékletű oldó izzítással jól alakítható, lágy homogén egyfázisú, $\alpha$ szilárd oldatot tartalmazó állapotra hőkezeljük, amelyet ezt követően melegen, a kívánt formára alakítjuk. Az alakítást követően az alkatrészt gyorsan lehütjük, ezzel megakadályozva durva kiválások keletkezését, amelyek a tulajdonságokat igen kedvezőtlenül befolyásolnák. Az alkatrész a végleges szilárdságát ezt követően egy kikeményítő hőkezelés során nyeri el. A jelentős szilárdságnövekedés a kikeményítés során kiváló finom precipitátumoknak köszönhető. Ennek a technológiai folyamatnak az elvi hőmérséklet-idő folyamata látható az 1 . ábrán.

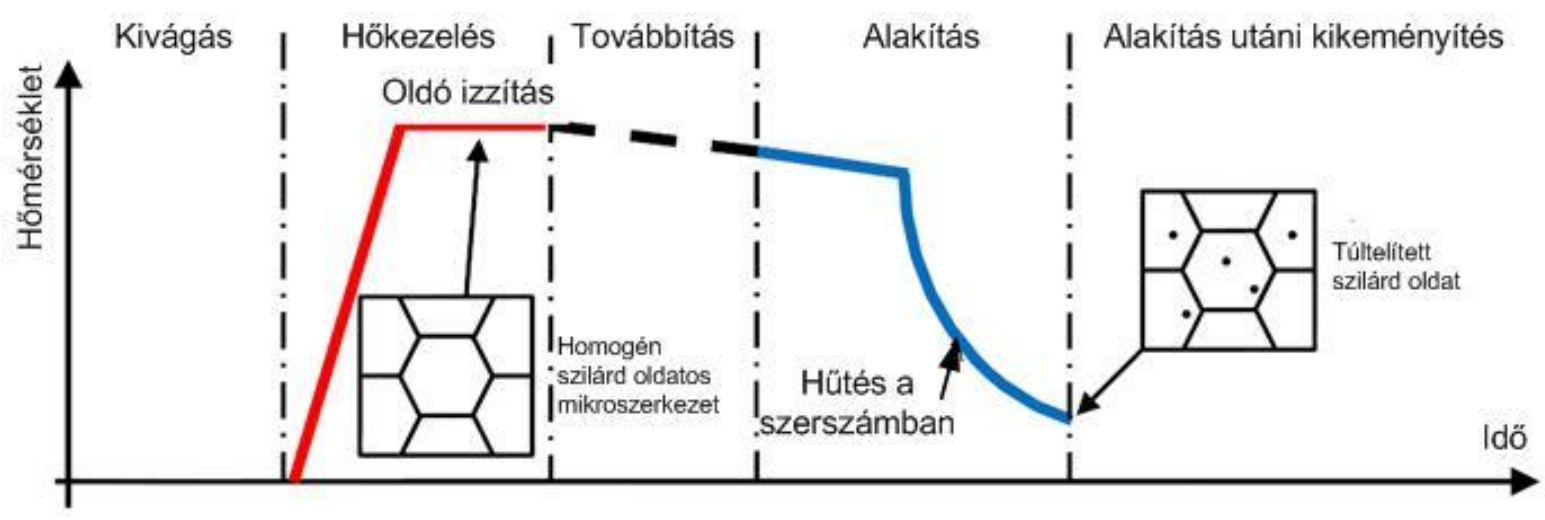

1. ábra. A Hot Forming and Quenching $\left(\mathrm{HFQ}^{\mathrm{TM}}\right)$ eljárás elvi hőmérséklet idő diagramja

Mivel vékony lemezekről van szó (alkatrésztől függően t=0,8-2,0 mm), az oldó izzítás csak néhány percet vesz igénybe. A kikeményítés ennél lényegesen hosszabb időt (akár néhány órát is) igényel. Ezt az időt azzal csökkentjük az ipari gyártási folyamatba beilleszthető ciklusidő elérése érdekében, hogy a szilárdságnövekedést biztosító kikeményítő hőkezelést, a gyártási sorba beépítve, a karosszéria festését követő kiégetés során nyeri el.

\section{Az anyagparaméterek meghatározása}

Mind a technológiai és a szerszámtervezéshez, mind pedig a folyamatok numerikus modellezéséhez nélkülözhetetlen egyrészt a megfelelő anyagmodellek kidolgozása, másrészt azoknak az anyagjellemzőknek a kísérleti meghatározása, amelyek az anyagmodellek gyakorlati felhasználásához is szükségesek.

\subsection{Az alkalmazott anyagmodellek}

Az alakítási hőmérséklet az alumínium ötvözetekre kidolgozott HFQ ${ }^{\circledR}$ eljárásnál melegalakításnak minősül. Melegalakítás során a hidegalakításhoz képest alapvetően különböző anyagmodellek alkalmazása szükséges a technológiai folyamat minél pontosabb leírása érdekében. Melegalakító eljárásoknál az anyag viselkedését a hőmérséklet és az alakváltozási sebesség is alapvetően 
befolyásolja. Az irodalomban különféle anyagmodellek találhatók, amelyek ezeket a hatásokat különböző mechanikai megfontolások alapján kidolgozott összefüggésekkel írják le. Melegalakító eljárásoknál jellemzően viszkoplasztikus anyagmodelleket alkalmaznak, esetenként a speciális alakváltozási körülményeket is figyelembe vevő alakváltozási állapotot is leíró módosításokkal (pl. kúszás, szuperképlékeny alakítás, viszkoplasztikus keményedés, megújulás és újrakristályosodás, stb. figyelembevételével). Ezekről a modellekről átfogó elméleti összefoglaló található Lin könyvében [1].

A projekt keretében Lin és munkatársai [2] nagyszilárdságú alumínium ötvözetek viselkedését pontosabban leíró, egységes viszkoplasztikus anyagmodellt (Unified Viscoplastic Material Modell) dolgoztak ki, a különféle melegalakítási folyamatok egységes leírására. Ebben a cikkben az anyagmodell részletes ismertetésétöl eltekintünk; ennek részletes elemzésére egy külön, önálló cikkben térünk vissza. Azonban a következő pontokban ismertetésre kerülö anyagvizsgálatok, és alakíthatósági elemzések tervezésénél és megvalósításánál a Lin és munkatársai által kidolgozott modellt alkalmazzuk [2].

\subsection{A HFQ® eljárásnál alkalmazott nagyszilárdságú alumínium ötvözetek anyagjellemzőinek meghatározása}

A HFQ ${ }^{\circledR}$ eljárásnál alkalmazott AA7075 nagyszilárdságú alumínium ötvözet mechanikai anyagvizsgálatához a lemez alapanyagokat a francia Constellium (CTE) projektpartner biztosította. A párizsi székhelyü cég a világon meghatározó szerepet tölt be a nagyszilárdságú alumínium alapanyagok fejlesztésében és gyártásában. A világszerte számos leányvállalattal rendelkező cég a repülőgépipar és az autóipar meghatározó alapanyag beszállítója. A Constellium a nagyszilárdságú alumínium ötvözetek egész sorát gyártja különböző fantázianevekkel:

- Surfalex ${ }^{\circledR}$ márkanévvel kiváló minőségü, nagyszilárdságú és kedvező alakíthatósági tulajdonságokkal rendelkező lemeztekercseket szállít elsősorban a különféle külső autópanelek gyártásához, amelyeknél a külső megjelenés különösen hangsúlyozott,

- Securalex® márkanévvel az előzőnél is nagyobb szilárdságú lemezek, a jármüvek ütközésállóságát növelő alkalmazásokhoz,

- Strongalex ${ }^{\circledR}$ és Ultralex ${ }^{\circledR}$ a fokozott nagyszilárdságú és ultra-nagyszilárdságú igényt jelentő alkatrészekhez, pl. az ún. B-oszlopok gyártásához,

- Formalex® a kimondottan nagy alakítási mélységü alkatrészekhez.

Az alábbiakban a vizsgálatokra rendelkezésünkre bocsátott lemez alapanyagok kémiai összetételét és mechanikai anyagjellemzőit ismertetjük. Az AA7075 anyagminőség vegyi összetételét a 2. táblázat mutatja az elemek tömegszázalékában.

2. táblázat. A vizsgálatoknál alkalmazott AA7075 lemez alapanyag jellemzö összetétele (tömeg\%)

\begin{tabular}{c|c|c|c|c|c|c|c|c|c|c}
\hline $\mathrm{Al}$ & $\mathrm{Mg}$ & $\mathrm{Si}$ & $\mathrm{Zn}$ & $\mathrm{Cr}$ & $\mathrm{Mn}$ & $\mathrm{Cu}$ & $\mathrm{Ti}$ & $\mathrm{Fe}$ & $\begin{array}{c}\text { Egyéb } \\
\text { egyenként }\end{array}$ & $\begin{array}{c}\text { Egyéb } \\
\text { összes }\end{array}$ \\
\hline $\begin{array}{c}87,1- \\
91,4\end{array}$ & $2,1-$ & $\max$ & $5,1-$ & $0,18-$ & $\max$ & $1,2-$ & $\max$ & $\max$ & $\max 0,05$ & $\max 0,15$ \\
\hline
\end{tabular}

A legfontosabb mechanikai anyagjellemzőket $\left(\mathrm{R}_{\mathrm{p} 0.2}, \mathrm{R}_{\mathrm{m}}, \mathrm{A}_{80}, \mathrm{HB}\right)$ az AA7075 anyagminőség szállítási állapotára (T6 hőkezeltségi állapotra) vonatkozóan a 3. táblázat tartalmazza. A T6 
hőkezeltségi állapot az oldó izzítást követően teljes mértékben mesterségesen öregített, kikeményített állapotot jelent.

3. táblázat. AA7075 anyagminöség mechanikai jellemzői, T6 állapotban

\begin{tabular}{l|c|c|c|c}
\hline Megnevezés & Folyási határ & Szakítószilárdság & Keménység & Fajlagos nyúlás \\
\hline Jel, mértékegység & $\mathrm{R}_{\mathrm{p} 0.2, \mathrm{MPa}}$ & $\mathrm{R}_{\mathrm{m}, \mathrm{MPa}}$ & $\mathrm{HB}$ & $\mathrm{A}_{80} \%$ \\
\hline Érték & 503 & 572 & 150 & 11 \\
\hline
\end{tabular}

\subsection{Az AA7075 alumínium ötvözet mechanikai anyagvizsgálata}

A projektben a mechanikai anyagvizsgálat elsősorban az alakításnál alkalmazandó alapanyagok valódi feszültség-valódi nyúlás diagramjainak meghatározását jelentette. Ezekre a diagrammokra mind a technológiai és szerszámtervezésnél, mind pedig az eljárás numerikus modellezésénél szükség van. Ez a HFQ ${ }^{\circledR}$ eljárás lényegéből következően különböző hőmérsékleteken, különböző alakváltozási sebességekkel végrehajtott egytengelyü húzóvizsgálatokat, melegszakító vizsgálatokat jelentett.

A hőmérséklet és az alakváltozási sebesség szabályozása szükségessé tette, hogy az egytengelyü húzóvizsgálatokat az intézetünkben található Gleeble-3500 termomechanikus vizsgáló berendezésen (fizikai szimulátoron) végezzük. A berendezés részletes ismertetése a projektben készült jelentésekben [3] és a berendezést gyártó Dynamic Systems Inc. weboldalán is elérhető [4]. A Miskolci Egyetem Anyagszerkezettani és Anyagtechnológiai Intézetének Gleeble-laboratóriumában üzembe helyezett Gleeble-3500 termomechanikus fizikai szimulátor fényképe a 2. ábrán látható.

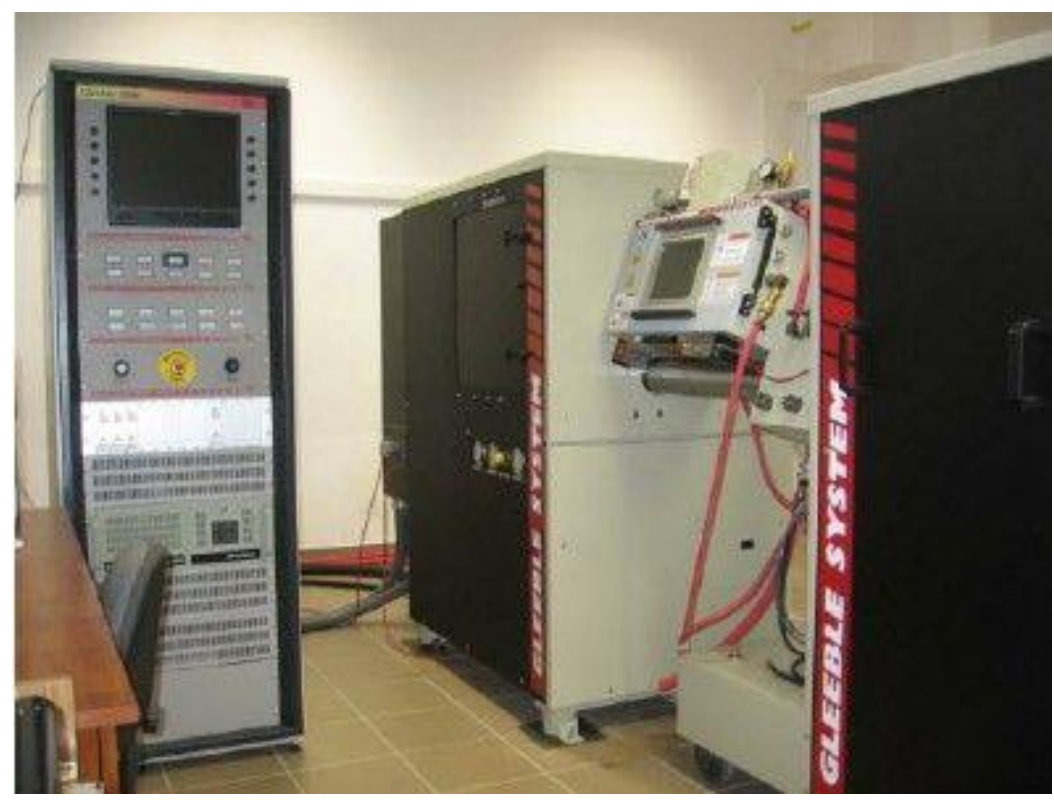

2. ábra. Gleeble-3500 termomechanikus fizikai szimulátor 
A vizsgálatokat az előzőkben ismertetett, a Constellium projekt partner által szállított lemez próbatesteken végeztük. A próbatestek kialakítása és méretei a 3. ábrán láthatók. A próbatest lemezvastagsága az alapanyag lemezvastagságával $(\mathrm{t}=2,0 \mathrm{~mm})$ egyezett meg.

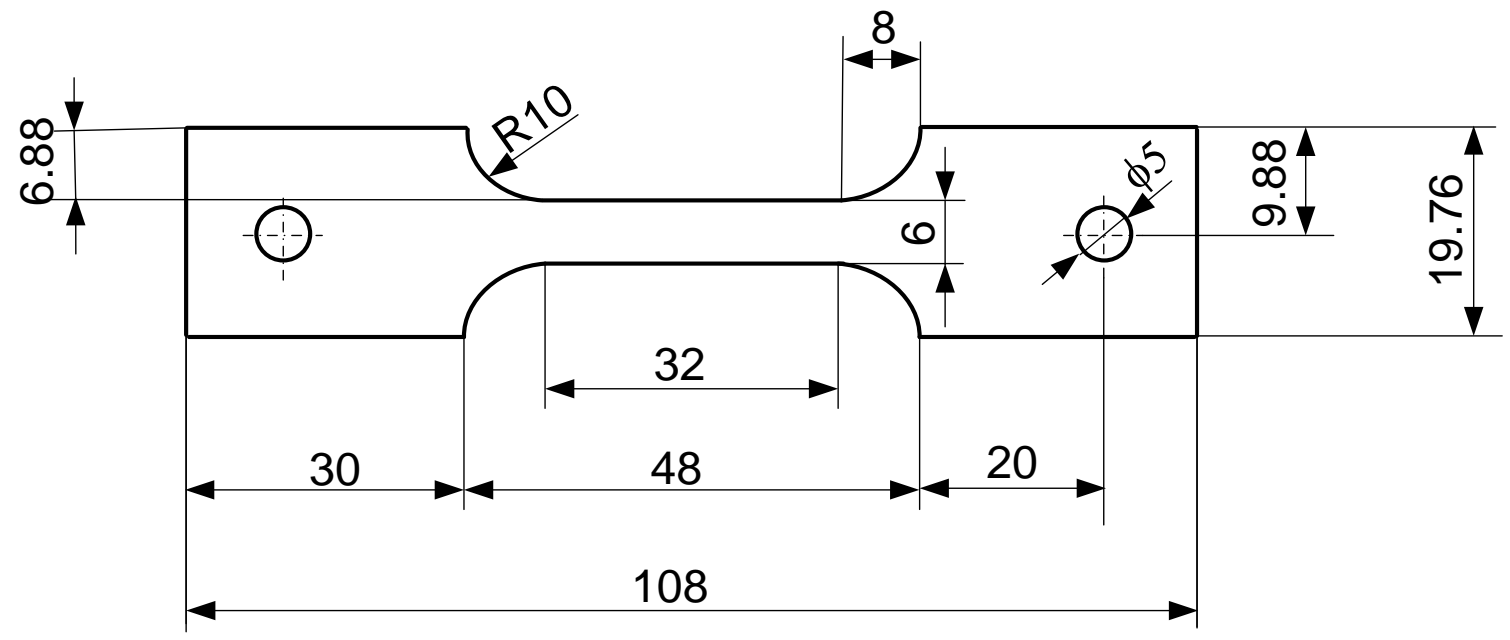

3. ábra. A próbatest kialakítás a méretekkel az egytengelyủ meleg szakítóvizsgálatokhoz

Az üzemi alakítási körülmények minél teljesebb modellezése, 5 különböző hőmérsékleten, 4 különböző, de a kiválasztás után nagypontossággal állandó értéken tartott, alakváltozási sebesség alkalmazását jelentette. A vizsgálatokat a 4. táblázatban összesített vizsgálati mátrix szerint végeztük. A vizsgálatokat a 4. táblázat szerinti 5 különbözö, de állandó értékủ hőmérsékleten végeztük. Minden hőmérsékleten elvégeztük a 3 . ábrán látható módon kialakított próbatestek egytengelyü szakítóvizsgálatát $\dot{\varepsilon}=1$ / s alakváltozási sebességgel, majd ezt követően a hőmérsékletet állandó értéken tartva $\left(\mathrm{T}=380^{\circ} \mathrm{C}\right.$ hömérsékleten) az alakváltozási sebességet változtattuk az $\dot{\varepsilon}=(1-10) 1 / \mathrm{s}$ intervallumban az alakváltozási sebesség hatásának tanulmányozása érdekében.

4. táblázat. A vizsgálati mátrix az alkalmazott hömérsékleti és alakváltozási sebesség értékekkel

\begin{tabular}{c|c|c|c|c|c}
\hline \multirow{2}{*}{$\begin{array}{c}\text { Alakváltozási } \\
\text { sebesség }\end{array}$} & $350^{\circ} \mathrm{C}$ & $380^{\circ} \mathrm{C}$ & $400^{\circ} \mathrm{C}$ & $450^{\circ} \mathrm{C}$ & $480^{\circ} \mathrm{C}$ \\
\hline & & $\sqrt{ }$ & & & \\
\hline $0.1 / \mathrm{s}$ & $\sqrt{ }$ & $\sqrt{ }$ & $\sqrt{ }$ & $\sqrt{ }$ & $\sqrt{ }$ \\
\hline $1 / \mathrm{s}$ & & $\sqrt{ }$ & & & \\
\hline $5 / \mathrm{s}$ & & $\sqrt{ }$ & & & \\
\hline $10 / \mathrm{s}$ & & & & & \\
\hline
\end{tabular}

A meleg szakítóvizsgálatok valódi feszültség-valódi alakváltozás diagramjai a 4. ábrán láthatók. A pontsorok a mérési eredmények pontjait, a folytonos vonalak a mérési pontokra illesztett trendvonalakat jelentik 


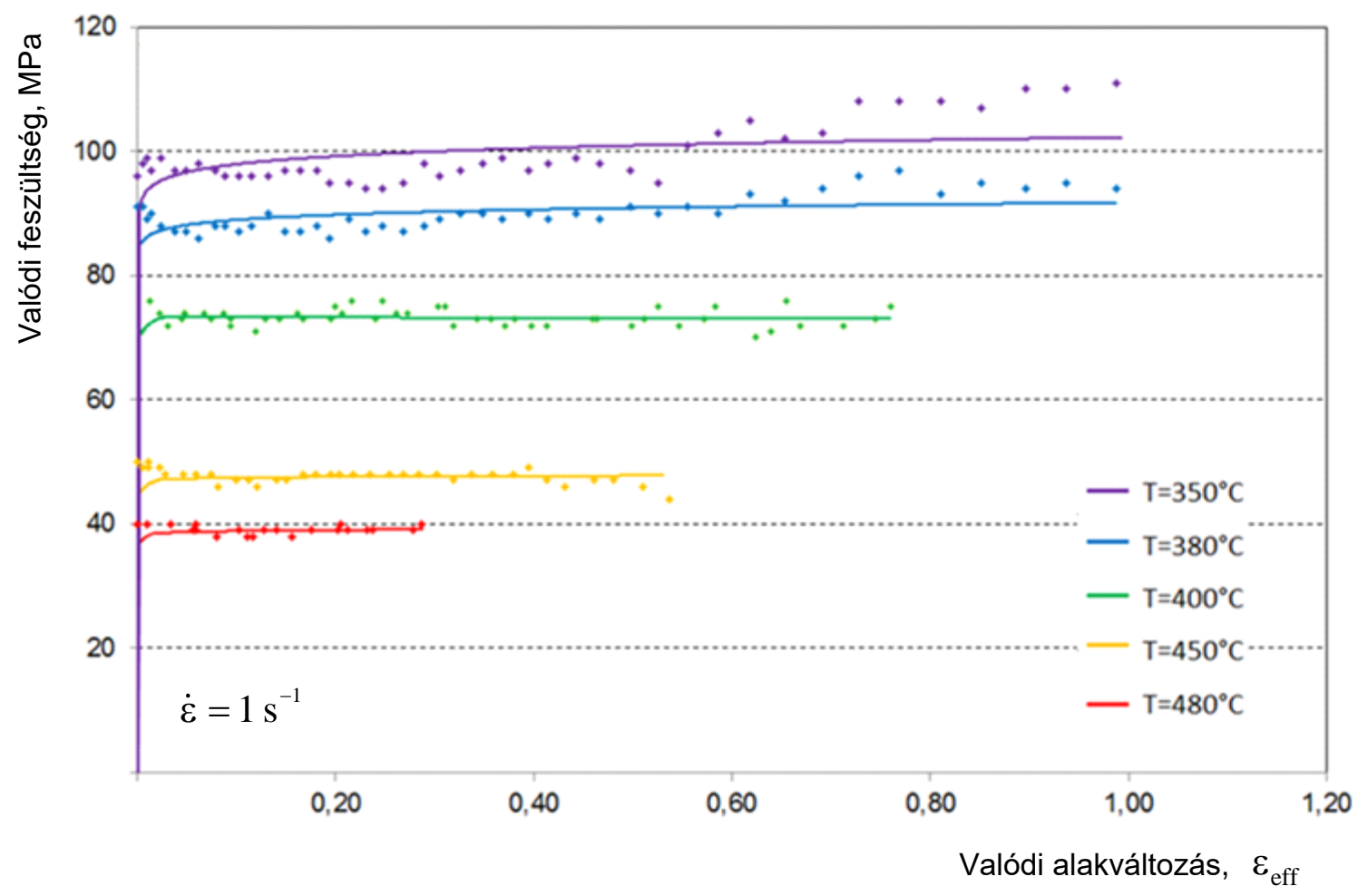

4. ábra. Melegszakító vizsgálati diagramok

A diagramon ábrázolt görbék a $\mathrm{T}=350-480^{\circ} \mathrm{C}$ hömérsékleteken, $\dot{\varphi}=1 / \mathrm{s}$ állandó alakváltozási sebességgel felvett mérési eredményeket mutatják.

A diagramok elemzéséből az alábbi lényeges következtetések vonhatók le:

- a valódi feszültség - valódi alakváltozás görbék a valódi feszültség értékeket illetően jól követik a melegalakításnál várt változásokat, azaz a növekvő hőmérsékleteken egyre csökkenő valódi feszültségeket mértünk. A valódi feszültségek csökkenése a növekvő hőmérsékletekkel a diszlokációk növekvő termikus aktiválódásával magyarázható: ez teljes mértékben megegyezik a melegalakításnál más anyagminőségek esetén is tapasztalt változásokkal;

- a mért valódi alakváltozások a $\mathrm{T}=350-400^{\circ} \mathrm{C}$-on végzett kísérleteknél többé-kevésbé ugyancsak a melegalakításnál várható tendenciát követik, ugyanakkor a $\mathrm{T}=450^{\circ} \mathrm{C}$-on és különösen a $\mathrm{T}=480^{\circ} \mathrm{C}$-on felvett diagramok a vártnál lényegesen kisebb valódi nyúlást mutatnak. Hasonló tapasztalatokról számolt be AA2024 minőségü alumínium ötvözetek vizsgálatánál Wang és Lin is [5]. A szakadásig elviselt nyúlás csökkenését a magasabb hőmérsékleten $\left(\mathrm{T}>450-480^{\circ} \mathrm{C}\right)$ a szemcsék közötti törési folyamatok mechanizmusainak dominánssá válásával indokolták.

A következő kísérletsorozatban az alakváltozási sebesség $(\dot{\varepsilon})$ valódi feszültség-valódi alakváltozás görbékre gyakorolt hatását tanulmányoztuk. A mérési eredményeket az 5. ábra mutatja: a pontsorok a mérési eredmények pontjait, a folytonos vonalak a mérési pontokra illesztett trendvonalakat jelentik. 


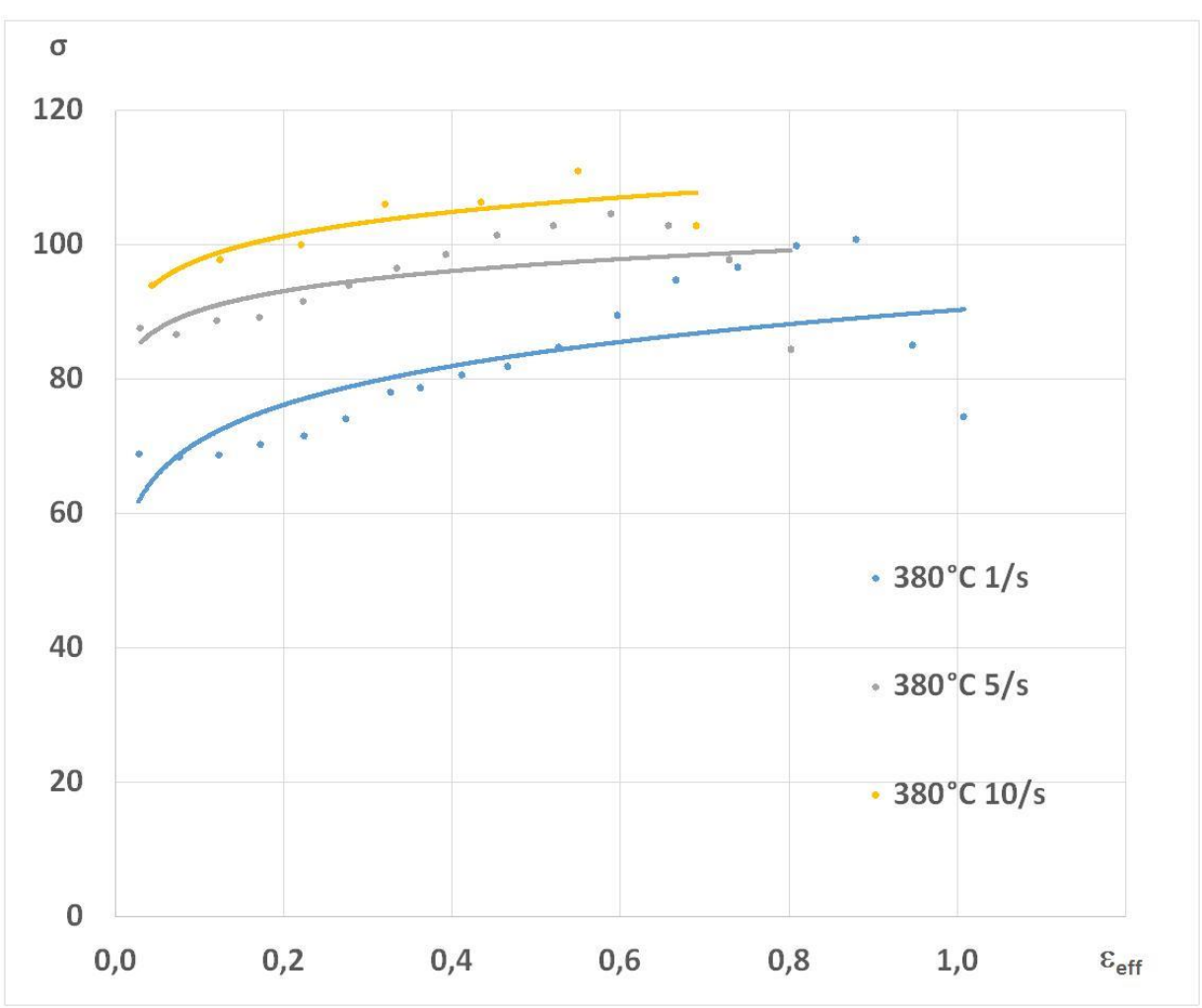

5. ábra. Az alakváltozási sebesség hatása a valódi feszültség-valódi nyúlás diagramokra

Az 5. ábrával kapcsolatban azt is meg kell jegyezni, hogy az eredeti vizsgálati mátrixban szereplő $\dot{\varphi}=0.1 / \mathrm{s}$ alakváltozási sebességre vonatkozó adatok méréstechnikai okok miatt nem szerepelnek. A diagramok elemzéséből az alábbi lényeges következtetések vonhatók le:

- a valódi feszültség értékek a növekvő alakváltozási sebességekkel növekednek, amint az a melegalakító eljárásoknál általánosan ismert;

- a növekvő alakváltozási sebességekkel a szakadásig elviselt nyúlás csökkenése is megfigyelhető: ez ugyancsak összhangban van a melegalakításnál tapasztaltakkal.

\subsection{Az AA7075 alumínium ötvözet alakíthatósági vizsgálata}

$\mathrm{Az}$ alakíthatósági vizsgálatokat ugyancsak a Constellium (CTE) projekt partner által biztosított $\mathrm{t}=2,0 \mathrm{~mm}$ vastagságú, AA7075 lemezanyagokon végeztük, amelynek alapvető mechanikai tulajdonságai az 1. és 3. táblázatban találhatók. A vizsgálatokat a melegszakító vizsgálatoknál bemutatott, Gleeble-3500 termomechanikus fizikai szimulátorral, izotermikus vizsgálati körülmények között, a tanszékünkön kidolgozott módosított Nakajima vizsgálat szerint végeztük [6].

\subsubsection{Az alakíthatósági vizsgálatnál alkalmazott próbatestek kialakítása és méretei}

A vizsgálatoknál alkalmazott próbatestek kialakítását és méreteit a 6 . ábra mutatja. A próbatesteket ф80 mm méretü körlapokból, a 6. ábrán látható kialakítással készítettük el. 


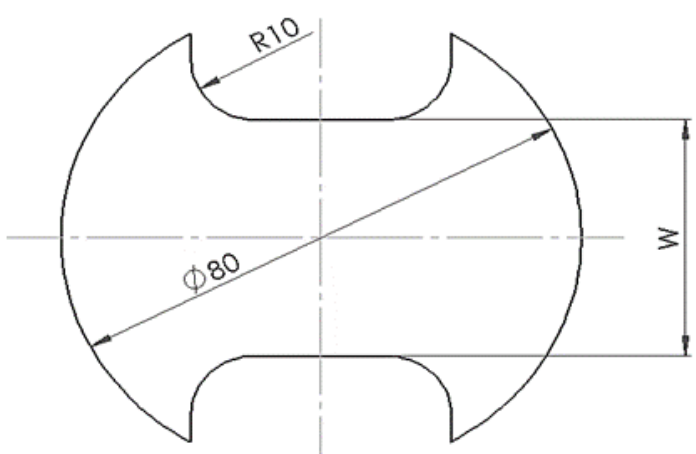

6. ábra. A módosított Nakajima vizsgálat vizsgálati próbatestjeinek kialakítása és méretei

Az ábrán látható $\mathrm{w}$ hídszélesség értékét annak megfelelően változtattuk, hogy különböző alakváltozási útvonalakat (alakváltozási történetet) tudjunk az egyes próbatestekkel megvalósítani. A különböző alakváltozási állapotokhoz tartozó w hídszélességeket a megfelelő alakváltozási útvonallal együtt az 5. táblázat tartalmazza.

5. táblázat. A különbözö alakváltozási történetekhez tartozó próbatest hídszélességek (w) értékei

\begin{tabular}{c|c|c|c}
\hline Geometria száma & Alakváltozási történet & $w(\mathrm{~mm})$ & $w / D$ \\
\hline 1 & Egytengelyü húzás & 12 & 0,15 \\
\hline 2 & Síkalakváltozás & 40 & 0,5 \\
\hline 3 & Biaxiális nyújtás & 80 & 1 \\
\hline
\end{tabular}

Az 5. táblázat szerint kialakított, három különböző alakváltozási történetet eredményező próbatest fényképe látható a 7. ábrán.
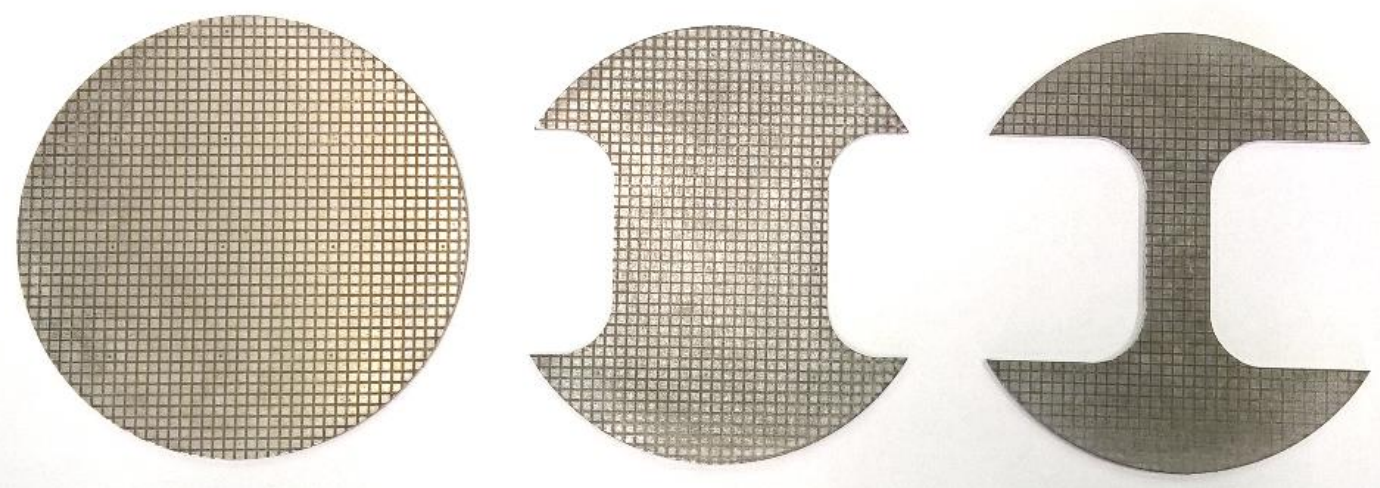

7. ábra. Az alakíthatósági vizsgálatoknál alkalmazott három különböző hídszélességü próbatest képe (a próbatesteken az optikai alakváltozásméréshez felvitt négyzetháló látható) 


\subsubsection{Az izotermikus alakíthatósági vizsgálat elrendezése és a vizsgálati mátrix}

Az alakíthatósági vizsgálatokat a 3.3. pontban ismertetett, Gleeble-3500 termomechanikus fizikai szimulátor berendezésen végeztük. Annak érdekében, hogy a jelentős alakítási sebességgel végzett vizsgálatok során a próbatestekre felvitt négyzetháló torzulását (a próbatest alakváltozását) a Vialux optikai mérőrendszerrel [7] folyamatosan vizsgálni tudjuk, egy speciális berendezést terveztünk a Gleeble-3500 berendezéshez, amelynek a müködését a következö pontban ismertetjük részletesen.

\subsubsection{A módosított Nakajima vizsgálathoz készített speciális vizsgáló berendezés}

A speciális vizsgáló berendezéssel szemben támasztott legfontosabb követelmény - amellett, hogy a Gleeble által biztosított hőmérséklet és alakváltozási sebesség kontrol megbízhatóan müködjön hogy a próbatest mélyítése közben folyamatosan nyomon követhetö legyen az alakított részen az alakváltozás. Ehhez optikailag hozzáférhetővé kell tenni a próba felületét a mélyítés során. Ehhez pedig szükséges a Gleeble berendezésen az alakító főmozgás irányának a Gleeble tengelyéhez képest 90-kal való „elfordítása”, amelyet a Gleeble terhelődugattyú mozgásának egy ékpályán való irányváltoztatásával valósítottunk meg. A speciális vizsgáló berendezés tervezésekor a fő célkitüzést, valamint a feladat szempontjából lényeges, további tervezési szempontokat vettünk figyelembe. A további tervezési szempontok alapján elvárásként fogalmaztuk meg, hogy a készülék legyen alkalmas:

- az alakítási határdiagram meghatározására tervezett hőmérséklet és alakváltozási sebesség paraméterek megbízható megvalósítására;

- a próbatest alakváltozásának folyamatos nyomon követésére a Vialux-AutoGrid optikai mérörendszerrel;

- a próbatestek gyors és megbízható megfogására az alakítás során;

- a 3.4.1. pontban ismertetett, módosított Nakajima próbatestek és a hozzátartozó bélyeg-matrica pár befogadására.

Ezeket a feltételeket kielégítő készülék elvi vázlata a 8. ábrán látható.

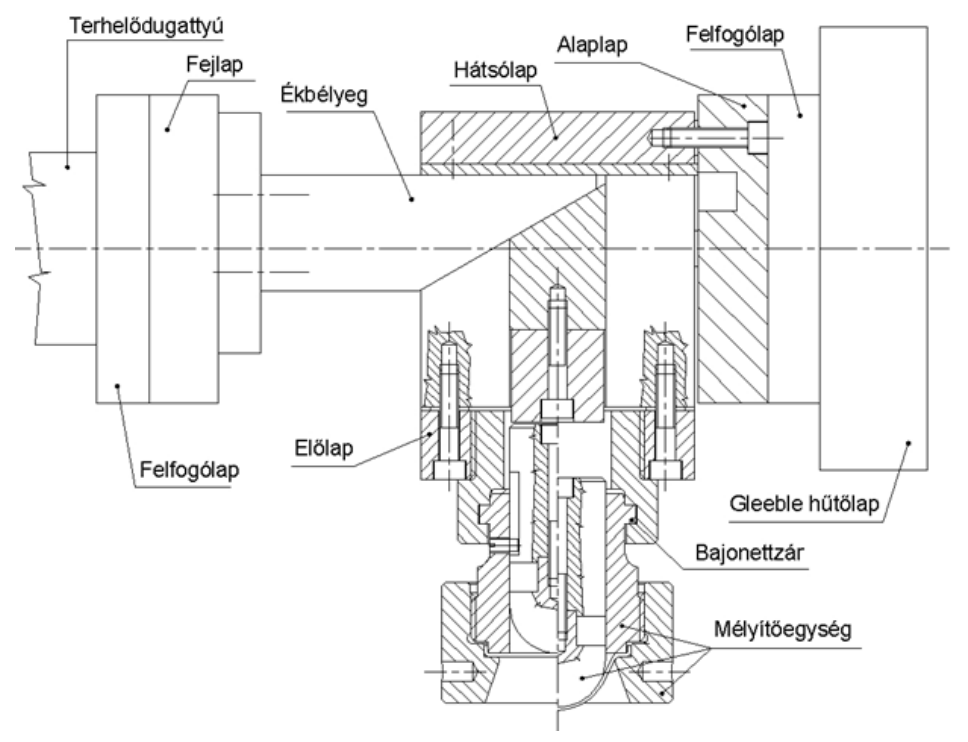

8. ábra. A módosított Nakajima vizsgálathoz a Gleeble-3500 berendezésre tervezett készülék 


\subsubsection{Az alakítási határgörbe vizsgálat és eredményei}

Az alakítási határdiagram meghatározását az előző pontokban leírt vizsgálati módszerrel és technikával a Gleeble-3500 berendezésen, az erre a célra kifejlesztett speciális készülék alkalmazásával végeztük. Az alakítási határgörbe három alakváltozási történetet megtestesítö pontsorozatát a 3.4.1. pontban ismertetett próbatestek alkalmazásával határoztuk meg. Az alakváltozások kiértékelését a Vialux-AutoGrid optikai alakváltozás mérö- és kiértékelő berendezéssel végeztük.

Az alakíthatósági vizsgálatokat, azaz az alakítási határdiagram meghatározását $\mathrm{T}=350,380$ és $420^{\circ} \mathrm{C}$ hőmérsékleteken, $\mathrm{v}=75,250$ és $400 \mathrm{~mm} / \mathrm{s}$ alakítási sebességekkel végeztük. Az alkalmazott hőmérséklet és alakítási sebesség paramétereket a technológiai paraméterek 6. táblázatban összefoglalt technológiai mátrixa mutatja.

A vizsgálatokat az első mérési sorozatban $\mathrm{v}=250 \mathrm{~mm} / \mathrm{s}$ állandó alakítási sebességgel, végeztük valamennyi ( $\mathrm{T}=350,380$ és $420^{\circ} \mathrm{C}$ hőmérsékleten, majd a következő mérési sorozatban a hőmérsékletet állandó értéken tartva $\left(\mathrm{T}=380^{\circ} \mathrm{C}\right)$, az alakítási sebességet változtattuk a 6. táblázatban megadott, $v=75,250$ és $400 \mathrm{~mm} / \mathrm{s}$ értékeknek megfelelően. Ezzel a módszerrel, lehetőségünk nyílt mind az alakítási hőmérséklet, mind pedig az alakítási sebesség hatásának elemzésére.

\section{6. táblázat. Az alakíthatósági vizsgálatoknál alkalmazott technológiai paraméterek mátrixa}

\begin{tabular}{c|c|c|c}
\hline \multirow{2}{*}{$\begin{array}{c}\text { Alakitási } \\
\text { sebesség }(\mathrm{mm} / \mathrm{s})\end{array}$} & $350^{\circ} \mathrm{C}$ & $380^{\circ} \mathrm{C}$ & $420^{\circ} \mathrm{C}$ \\
\cline { 2 - 4 } & & $\sqrt{ }$ & \\
\hline $75 \mathrm{~mm} / \mathrm{s}$ & $\sqrt{ }$ & $\sqrt{ }$ & $\sqrt{ }$ \\
\hline $250 \mathrm{~mm} / \mathrm{s}$ & & $\sqrt{ }$ & \\
\hline $400 \mathrm{~mm} / \mathrm{s}$ & & \multicolumn{3}{|c}{ Hérséklet $\left({ }^{\circ} \mathrm{C}\right.$} \\
\hline
\end{tabular}

A kísérleti eredményekből megszerkesztettük az AA7075 alumínium ötvözet alakítási határdiagramját (FLD). A 9. ábra a $\mathrm{v}=250 \mathrm{~mm} / \mathrm{s}$ állandó alakítási sebességgel $\mathrm{T}=350,380$ és $420^{\circ} \mathrm{C}$ hőmérsékletekre vonatkozó alakítási határgörbéket mutatja, míg a 10 . ábra a $\mathrm{T}=380^{\circ} \mathrm{C}-\mathrm{on}, \mathrm{v}=75,250$ és $400 \mathrm{~mm} / \mathrm{s}$ alakítási sebességgel elvégzett kísérletek eredményeit foglalja össze.

A 9. ábrából jól látható, hogy az alakítási határgörbe (FLC) a $\mathrm{T}=350$ és $380^{\circ} \mathrm{C}$ hőmérsékleteken követi azt a tendenciát, amelyet az egytengelyü meleg szakítóvizsgálatoknál is tapasztaltunk, azaz a hőmérséklet növelésével az alakíthatóság a teljes alakváltozási tartományban növekedett. $\mathrm{A} \mathrm{T}=420^{\circ} \mathrm{C}$ hömérsékleten azonos alakítási sebességgel meghatározott alakítási határgörbe, a várakozásunkkal szemben mind a $350^{\circ} \mathrm{C}$, mind pedig a $380^{\circ} \mathrm{C}$ hömérsékletü $\mathrm{FLC}-$ hez képest kisebb alakíthatóságot mutat. Ugyanakkor azt is megállapíthatjuk, hogy a három különböző hőmérsékleten, azonos alakítási sebességgel $(\mathrm{v}=250 \mathrm{~mm} / \mathrm{s})$ felvett alakítási határgörbék lényegében követik azt a tendenciát, amit az egytengelyủ szakítóvizsgálatoknál is tapasztaltunk. Ennek fémtani, anyagtudományi magyarázataként az ott leírtakat tekintjük érvényesnek.

A következő kísérletsorozatban az alakítási sebesség hatását elemeztük az 6. táblázatban megadott paraméterekkel, nevezetesen a legkedvezőbb alakíthatóságot eredményező $\mathrm{T}=380^{\circ} \mathrm{C}$ hőmérsékleten, három különböző ( $\mathrm{v}=75,250$ és $400 \mathrm{~mm} / \mathrm{s})$ alakítási sebességgel határoztuk meg az AA7075 alumínium ötvözetre vonatkozó alakítási határgörbéket. 


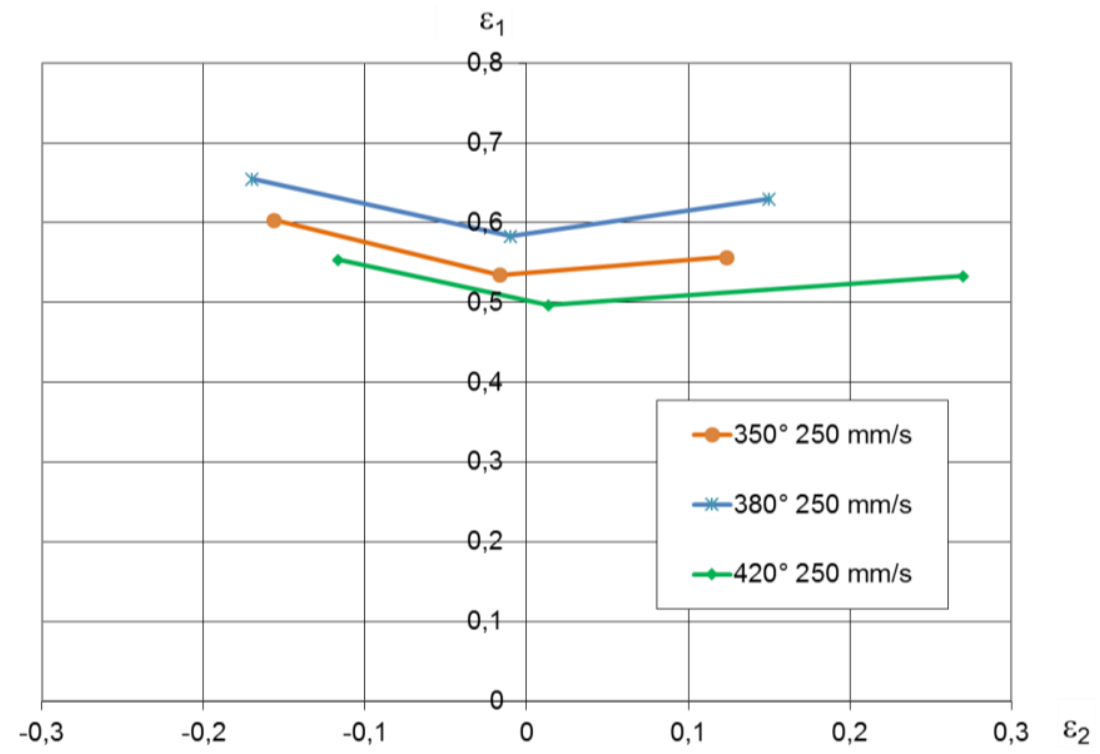

9. ábra. Az AA7075 alumínium ötvözet alakítási határdiagramja különböző hőmérsékleteken, v=250 mm/s alakítási sebesség esetén

A 10. ábrából jól látható, hogy az alakítási határgörbék helyzete $\mathrm{T}=380^{\circ} \mathrm{C}$ hőmérsékleten az elvárt módon követi az alakíthatóság változását az alakítási sebesség változásával, nevezetesen a növekvő alakítási sebességgel az alakítási határgörbék a csökkenő alakíthatóság irányába tolódnak el.

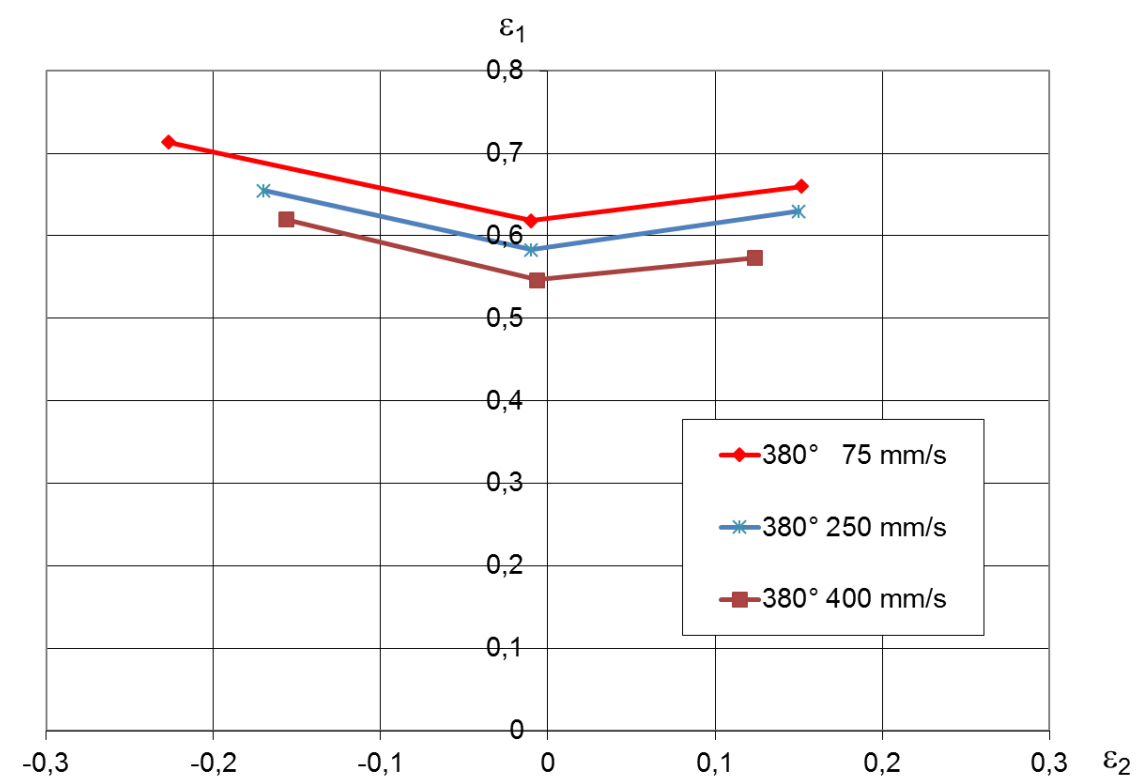

10. ábra. Az AA7075 alumínium ötvözet alakítási határdiagramja különböző alakítási sebességek esetén, $\mathrm{T}=380^{\circ} \mathrm{C}$ alakítási hömérsékleten 


\section{4. Összefoglalás}

A cikkben a LoCoMaTech - Low Cost Materials Processing Technologies for Mass Productions of Lightweight Vehicles elnevezésü - H-2020 Európai Uniós projektben a Miskolci Egyetem Anyagszerkezettani és Anyagtechnológiai Intézetének közremüködésével végzett alakítástechnológiai kutatásokról adtunk rövid áttekintést.

A projekt keretében 9 ország 19 intézménye vett részt a Hot Forming and Quenching (HFQ $\left.{ }^{\circledR}\right)$ eljárás ipari hasznosítását megalapozó, sokoldalú kutatómunkában. Az intézet projektben közremüködö munkatársainak egyik fö kutatási feladatát képezte a nagyszilárdságú alumínium ötvözetek - különösen az AA7075 repülőgépipari és autóipari alkalmazások szempontjából kiemelt jelentőségü alapanyag - melegalakítási körülmények közötti viselkedésének vizsgálata. E témakörben, az alakítás szempontjából kiemelten fontos két területet elemeztünk, nevezetesen, az ötvözet valódi feszültség-valódi nyúlás görbékkel jellemezhető keményedési tulajdonságait, valamint az ötvözet melegalakítási körülmények közötti alakíthatóságát, amelyet az alakítási határdiagramok különböző hőmérsékleten és változó alakítási sebességekkel meghatározott alakítási határdiagramjainak a felvételével vizsgáltunk.

\section{Köszönetnyilvánítás}

A cikk a "Low Cost Materials Processing Technologies for Mass Production of Lightweight Vehicles (LoCoMaTech)" projekt keretében végzett kutatómunka eredményeiböl közölt szemelvényeket. A projekt az European Commission támogatásával valósult meg (Grant No: H2020-NMBP-GV-2016), amelyért a szerzők e helyen is köszönetüket fejezik ki.

\section{Irodalom}

[1] Lin, J.: Fundamentals of materials modelling for metals processing technologies, World Science Publication Co. - Imperial College Press, 2015. pp. 1-512.

[2] Lin, J., Cao, J. and Balint, D.: Development of unified constitutive equations for hot forming processes, Journal of Mechatronics and Manufacturing Systems, 4 (2011) pp. 387-401. https://doi.org/10.1504/IJMMS.2011.043078

[3] Tisza, M., Kovács, P., Kuzsella, L., Lukács, Zs.: Recommendation of material testing for the HFQ ${ }^{\circledR}$ forming, Research Report in LoCoMaTech H-2020 project (H2020-NMP-08-2016), University of Miskolc, Miskolc, 2018. pp. 1-31.

[4] Dynamic Systems Inc. Gleeble-3500 thermo-mechanical physical simulator, https://www.gleeble.com/products/gleeble-systems/gleeble-3500.html

[5] Wang, L., Strangwood, M., Balint, D., Lind, J., Dean, T.: Formability and failure mechanisms of AA2024 under hot forming conditions, Materials Science and Engineering, 528 (2011) pp. 26448-2656. https://doi.org/10.1016/j.msea.2010.11.084

[6] Tisza, M., Budai, D., Kovács, P., Lukács, Zs.: Investigation of the formability of aluminium alloys at elevated temperatures, Materials Science and Engineering 159 (2016) 012012 https://doi.org/10.1088/1757-899X/159/1/012012

[7] Kovács, P.: Alakítási határdiagramok elméleti és kísérleti elemzése, PhD értekezés, Miskolci Egyetem, 2012. pp. 1-123. 